\title{
How social democrats may become reluctant radicals: Thomas Piketty's Capital and Wolfgang Streeck's Buying Time
}

DOI:

$10.1177 / 1474885115601602$

\section{Document Version}

Accepted author manuscript

Link to publication record in Manchester Research Explorer

Citation for published version (APA):

Ronzoni, M. (2015). How social democrats may become reluctant radicals: Thomas Piketty's Capital and Wolfgang Streeck's Buying Time. European Journal of Political Theory. https://doi.org/10.1177/1474885115601602

\section{Published in:}

European Journal of Political Theory

\section{Citing this paper}

Please note that where the full-text provided on Manchester Research Explorer is the Author Accepted Manuscript or Proof version this may differ from the final Published version. If citing, it is advised that you check and use the publisher's definitive version.

\section{General rights}

Copyright and moral rights for the publications made accessible in the Research Explorer are retained by the authors and/or other copyright owners and it is a condition of accessing publications that users recognise and abide by the legal requirements associated with these rights.

\section{Takedown policy}

If you believe that this document breaches copyright please refer to the University of Manchester's Takedown Procedures [http://man.ac.uk/04Y6Bo] or contact uml.scholarlycommunications@manchester.ac.uk providing relevant details, so we can investigate your claim.

\section{OPEN ACCESS}




\title{
How social-democrats may become reluctant radicals
}

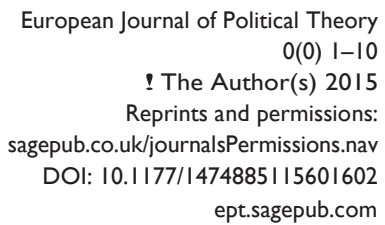

European Journal of Political Theory $0(0) \mathrm{I}-10$

! The Author(s) 2015 Reprints and permissions: sagepub.co.uk/journalsPermissions.nav DOI: $10.1177 / 1474885115601602$ ept.sagepub.com

(s)SAGE

\section{Miriam Ronzoni}

University of Manchester, Manchester, UK

\begin{abstract}
The continuing ramifications of the financial crisis of 2007-2008 have forced social scientists to raise fundamental questions about the relationship between capitalism, democracy and inequality. In particular, Thomas Piketty's Capital and Wolfgang Streeck's Buying Time focus, respectively, on the economic and on the political contradictions of capitalistic societies. Piketty argues that capitalism naturally tends towards the exacerbation of rent-based wealth inequality, whereas Streeck suggests that capitalism and democracy are ultimately incompatible. A striking feature of these two contributions is that their authors are social-democrats, not Marxists or radical anticapitalist thinkers. In this review article, I illustrate how the combination of socialdemocratic convictions and the acknowledgment that capitalism cannot be tamed generates interesting tensions between the diagnosis offered by the two monographs and the solutions that are proposed. I end the piece by raising two remarks on the implications that this tension might have for normative political theory. On the one hand, it is time for theory to do more work on political action and agency. On the other, liberal egalitarian theorists might have to acknowledge that they are in the same predicament as Piketty and Streeck: social-democracy is their ideal, yet it is perhaps unattainable. If this is the case, liberal egalitarians might be committed to adopt a more confrontational attitude towards capitalism: they might have to become reluctant radicals.
\end{abstract}

\section{Keywords}

Capitalism, democracy, wealth inequality, social-democracy, liberal egalitarianism, anticapitalism

The continuing ramifications of the financial crisis of 2007-2008 have forced social scientists to raise again fundamental questions about the relationship between capitalism, democracy and inequality, which had been put aside for several decades. Is capitalism compatible with democracy? Does it really generate invaluable societal benefits by raising living standards for all? And does it really reward merit and

Corresponding author:

Miriam Ronzoni, University of Manchester, Arthur Lewis Building, Oxford Road, Manchester MI3 9PL, UK.

Email: miriam.ronzoni@manchester.ac.uk 
effort? Two recent books have posed those questions in particularly pressing ways. With the support of an unprecedented quantity and quality of data, Piketty's Capital in the $21^{\text {st }}$ Century tells us that capitalism does not need high levels of growth and innovation except in extraordinary circumstances, naturally tends to exacerbate wealth inequality, and is thus in tension with the official narrative of merit, dynamism, benefit to greater society and equality of opportunity that is usually attached to market economies. Wolfgang Streeck's Buying Time: The Delayed crisis of Democratic Capitalism urges us to see capital as a political actor proper, and one whose agenda is characterised by impatience towards regulation and democratic accountability. As a result of the exercise of such agency, contemporary advanced societies - and European ones in particular - have gradually been transformed, through a series of crises, into actors who consider their creditors, rather than their citizens, as the constituency they ought to be accountable to.

The intellectual and political pedigree of their authors is interesting in and of itself. Capital and Buying Time are arguably two of the most radical critiques of 21st century capitalism written after the financial crisis - yet they have been written by prominent mainstream scholars, not by Marxists. Piketty and Streeck come from rather different traditions, but they are both, fundamentally, social-democrats. Thomas Piketty is a French economist whose CV boosts degrees and appointments in elite French and American institutions. A firm believer in the virtues of market economies and a brilliant representative of the mainstream economic methods that are taught at those elite schools, his work is now considered by some to offer, somewhat ironically, the most acute general critique of capitalism after Marx. Wolfgang Streeck is a German economic sociologist with an academic training grounded in the Frankfurt School, and in the crisis theory that informed Marxist approaches to the social sciences in the $60 \mathrm{~s}$ and $70 \mathrm{~s}$. He was, however, long persuaded that this radical perspective was mistaken, and even became an advisor to the Schro"der SPD/Greens coalition government and a supporter of some of its most 'Third Way' labour market reforms during the $90 \mathrm{~s}$. Now, after studying European welfare states and the process of European integration for almost 40 years, his optimism has faded again, and he has provided an insightful grand theory of the mutual incompatibility between capitalism and democracy in the long run.

I shall here first provide a synthesis of the main claims made in these two important monographs. I shall then make some remarks on both their profound commonalities and their crucial differences in approach and spirit. I will argue that the combination of social-democratic convictions and the acknowledgment that capitalism cannot be tamed generates interesting tensions between the diagnosis offered by the two monographs and the solutions that are proposed. Finally, I shall put forward two observations which might be of particular interest to political theorists. 
In Capital, Piketty (2014) spells out and interprets the findings of a (largely collaborative) research conducted over more than a decade, looking at long-term trends in income and especially wealth inequality by combining statistical methods and the kind of archival research that is usually more common among historians than economists. And these are sobering findings indeed. In the 18th and 19th centuries, western European society was highly unequal (much more so than North America), characterised by low growth, and rents - rather than income through business activity - constituted the default way to become and remain wealthy. The capital-income ratio was fairly stable across time at a fairly high level, meaning that most income came from ownership of assets rather than paid wages, wealth was almost entirely private and it was concentrated in a few hands - it was a society dominated by a rigid class of parasitic rentiers, not entrepreneurs. What is more, in spite of popular narratives, industrialisation did not change that - only the sheer destruction of the two world wars and the Great Depression did. The reduction of inequality in the 30 years between the end of WWII and the mid-1970s was the consequence of the sheer equalising power of the destruction of a lot of private wealth and the opportunities that created. It allowed for high growth (stimulated, in the first instance, by the effort of reconstruction, and then by political regulation), and opened up a window of opportunity for progressive policy-making (Keynesian economic policy, high taxes, inflation, labour market regulation, etc.). However, from the 1980s onwards, capital had started to recover from the shock. As Piketty (2014) insightfully observes (164-198), the internal structure of capital is radically different in the early 21st century compared to the Belle Époque, as the contemporary 1\% mainly owns complexfinancial packages rather than land; yet the capital-income ratio is roughly the same - and the unequalising effects of that will soon become even more evident than they already are. The ratio was much lower during the 30 years following WWII, known by the French as the Trente Glorieuses - but those three decades, not the Belle Époque or our age, are the exception. On many counts, things are starting to look worryingly similar to the late 19th century, and here Piketty (2014) makes two striking points. First, the trend towards inequality, much like before the 20th century, is stronger in Europe than in the US (271-303; 336-376). Second, much like in the 19th century, wealth inequality is more striking than income inequality (ibid.) - capitalism rewards rent-seeking behaviour, not effort or dynamic innovation. This, Piketty argues, is due to the fact that, other things being equal, the rate of return on wealth is higher than the rate of economic growth: $r>g(25-27 ; 232-$ $233 ; 353-361)$. In the aftermath of WWII, other things were not equal - but they are now. If rents are more profitable than growth, capitalistic societies 'naturally' stabilise at an equilibrium of low growth, where the share of income that goes to labour becomes smaller and smaller. High growth and intensive political regulation of the kind that the extraordinary shocks of the first half of the 20th century allowed to happen can in principle counteract this law, but there is no natural countertendency to $r>g$ in capitalistic economies. Patrimonial capitalism is the norm, innovation and social-democratic peace the exception. If this is the case, Piketty concludes, we need much more radical policy instruments than was 
previously thought to counteract this trend - such as very steep wealth (not only income) taxation (up to 80\%), global institutions to collect revenuestransnationally, and strong measures to counter capital flight and tax competition, starting from the EU and the Eurozone (Piketty et al., 2014). We must, in other words, actively cause another 'exception' of sorts throughradical policy means and intense global regulation.

In many ways, Buying Time tells us the political side of the economic story told in Capital. Streeck argues that Frankfurt-style crisis theory was right in predicting that democratic capitalism would experience a crisis of legitimation at some pointbut wrong in assuming that those who would question its legitimacy would be the masses. Instead, what has been happening in advanced economies since the 1970sis a revolt of capital - which is 'an actor, not a machinery' - against what it perceives to be the 'cage-like institutional framework of the post-1945 "social-market economy"' (19). From the 1970s onwards capital started to 'go on strike' against the 'conditions which capitalism had had to accept after 1945 in order to remain politically acceptable in a rivalry of economic systems' (26). It was capital, not labour, which started to perceive the mixed economy of late capitalism as illegitimate-and to resist it. The book is then a diagnosis of this increasingly successful strategy of resistance, and of the attempts of states to 'buy time' against it - thereby undergoing a series of crises. Streeck analyses several features of the resistance strategy set up by capital - the book is extremely complex in this respect, and perhaps not always crystal clear to the Anglo-American reader, but two elements are worth highlighting.

First, Streeck puts great emphasis, unsurprisingly, on how the neoliberal revolution attempts to undercut the legitimacy of high-tax regimes through ideological means (51-55). Second, drawing on Kalecki (1943), he argues that capital becomes unwilling to invest if the unemployment rate gets too low, even if investment remains overall profitable, in order to prevent labour from gaining too much bargaining power (25). This 'investment strike', Streeck argues, has played a major and underappreciated role in the past 40 years - a point which resonates quite strongly with Piketty's claim that capital is interested in growth only up to a point, and only under very specific circumstances. In the face of this resistance, what can the state do? Streeck's sobering argument is that it can only delay the inevitable final crisis by 'buying time' through political strategies which temporarily do the trick, but which are not sustainable in the long run and generate further crises.

The book is then structured around an analysis of this progressive wave of crises. First, advanced economies from the 1970s onwards used inflation as a policy tool. This, however, predictably led to a wage-price spiral and to economic stagnation. Enter Thatcher, Reagan and neoliberalism. Second, states recurred to borrowing as a way of achieving social peace - since this enabled them, temporarily, to avoid high taxation on the one hand whilst maintaining existing social programs on the other, thus catering to both capital and labour. This, however, was not sustainable in the long run, and by the mid-1990s creditors started to express their impatience rather forcefully. Enter fiscal consolidation, budget cutting and large-scale privatisation. In the mid-1990s, however, labour was still 
sufficiently organised and citizens sufficiently vocal; hence, budget cutting with no carrot to compensate for it would have been too disruptive from a social and political point of view. As a result, states widely deregulated the system of private credit - allowing individuals to incur debt to sustain their consumption levels. Enter the 2007-2008 financial crisis and the Great Recession. This, Streeck claims, was the last temporary crisis before the final one - the one which led to the 'consolidation state (97)'. The consolidation state is basically the outlook of 'democratic' politics brought about by the current austerity regime - a system which turns off the taps on private credit but refuses to reconsider budget cutting, since undermining 'business confidence' is considered unacceptable. ${ }^{1}$ In the consolidation state, markets should be spared from the cost of rescuing insolvent states; insolvent states should be prevented from declaring unilateral default; devaluation of debt can only occur gently, in a way that smoothens out the costs of the process for investors; failing banks should not be nationalised, but rescued with public funds; and more and more economic policy should be performed by 'independent', democratically unaccountable bodies; technocratic governments and grand coalitions should be preferred to ideological majorities. We have come full circle: The consolidation state considers its creditors, and not its citizens, to be the constituency it should be accountable to. In an insightful working paper, Peter Mair $(2009)^{2}$ had observed how difficult it is, for the governments of advanced democracies in the 21st century, to act 'responsibly' towards external constraints and legacies and to be representative of the people they govern at the same time. Buying Time argues that, in a way, the dilemma has been solved by changing the constituency that should be represented to begin with. The King is naked:capitalism and democracy are mutually incompatible. Buying Time moves then on to highly pessimistic reflections on the role of the Eurozone in accelerating this process (97-164). The European project, Streeck argues, has become the main instrument through which the enforcement of the consolidation regime (writ large) has occurred. The only possible source of hope for European democracies, Streeck then concludes, is to regain fiscal and monetary sovereignty, and thereby some policy discretion. The foolish experiment of monetary union should be abandoned, and we should instead aim at a patient reconstruction of democracy at the national level under a new permissive Bretton Woods-like system, which would authorise devaluations.

Capital and Buying Time have crucial common elements. First, both books are motivated by a strong conviction that the European social model was a highly desirable but extremely unstable equilibrium. Second, and relatedly, they both single out Europe, rather than the US, as the most interesting case study, precisely because the central tensions are clearest there. Third, they struggle to reconcile their nostalgic sympathy for postwar mixed economies with the increasingly acute awareness that Marxists were probably partly right in denouncing socialdemocracy as a self-deception, as an illusion that capital could be tamed. Indeed, 
I would venture the judgement that, in spite of the different disciplinary approach and intellectual background of their authors, these are two books about the same topic. They address, respectively, the economics and the politics of the same phenomenon: the crisis of social-democratic optimism. Both authors are persuaded in a sense, much in the same way as most liberal egalitarian political theorists - that the European social model which characterised the three decades after WWII was arguably the best possible reconciliation of freedom, equality and efficiency that complex societies have ever managed to achieve. In short, they still endorse socialdemocracy as an ideal. They have, however, come around to recognising the grain of truth in Marxist and other radical critiques of capitalism: namely, that the democratic control of capital which characterised the European welfare state of the Trente Glorieuses was a fragile, unique and unstable construct, rather than the solution to tame capital once and for all. Capital can and most often does find a way to turn wild again. Thus, even if social democracy remains the ideal, the socialdemocratic reading of reality must largely be questioned. However, the extent of this questioning and the normative implications that the two authors draw from it diverge significantly - as their two monographs, their interventions in public debates (Piketty et al., 2014; Streeck, 2013) and an exchange between the two at the Congress for European Studies in Paris in July 2015 illustrate. In what follows, I shall suggest that for both, however, the combination of social-democratic convictions and the acknowledgment that capitalism cannot be tamed gives rise to interesting ambivalences. There is, in particular, a tension between their diagnoses and the solutions they offered. It is as if both authors are hesitating on the edge of a steep cliff, wondering whether they should jump - and become radical anticapitalists - or not. Political theorists of liberal egalitarian convictions, I shall suggest at the end of this review article, might be stuck in the same predicament.

In a way, Piketty is more reluctant to give up on social-democratic optimism. In Part Four of Capital, he asks: if the dynamics of inequality are those which I have identified so far-namely, if 'forces of divergence' are particularly obstinate under capitalism, bar exceptional shocks - how, if at all, can we structure policy to oppose or at least mitigate such tendencies? Piketty's answer is bold: a highly progressive, global tax on capital. This, he adds, might be a utopian project in the short run (and perhaps in the long run, too), but nevertheless constitutesthe regulative blueprint that we should adopt to reach any more realistic, midterm goals (515-518). This conclusion is quite puzzling. It suggests that, once we have identified a problem, the solution is to find the optimal policy to 'fix' it. It reveals the persuasion that politics is fundamentally about making citizens understand what the problems are in a reasoned dialogue, and that the political will - and power - to act in the right direction will follow. This is a mixture of liberal and social-democratic optimism in their purest form. However, if Piketty's analysis is correct, and if Streeck is equally correct that Piketty's economic story has a political side, knowing the truth will not automatically motivate citizens and policymakers to fix things. If patrimonial capitalism is back, then surely its determination and capacity to influence political power is too - as Streeck so eloquently argues. And if this is the case, then surely the problem is not to identify the optimal policy, 
but to think about how to gather the sufficient counter-power to put any progressive policy back on the agenda to begin with. In other words, we need less policy and more politics: The emphasis should be more on political action and political processes than on which cure to put forward once the political power to put forward a cure at all has been achieved. Both the rise of economic elites and their capacity to use globalisation in their favour - by threatening capital flight, to mention but the most obvious example - have undermined the capacity of other sectors of society to participate in democratic politics, whether through parties or unions. If this is the case, the central question is then how to reclaim some control over our democracies - how to generate the political conditions under which the right policies and institutions could be put on the table to begin with. I am not thereby implying that Piketty should have the solution to these problems - as an economist, this is not his job. I am, however, puzzled by the absence of a more explicit acknowledgment of this hurdle. Our main problem is not what the precise content of the normative Part Four of Capital should be - which radically progressive policy agenda is the optimal one - but how to reach a place where something resembling the content of any possible Part Four can be back on the table at all.

Streeck certainly cannot be criticised for leaning on to social-democratic optimism in this straightforward way. His book, as wehave seen, is the political flipside of Capital. If 'capital is back' as an aggressive political actor and not only as the owner of the lion's share of wealth, then no utopian policy design can help. This is also what Streeck forcefully claims in his public debate with Jürgen Habermas (Streeck, 2013), where he denounces insisting on the possibility of a more progressive agenda of European integration today as not only futile but quite possibly actually positively harmful. However, it is not clear that his manifesto for a recovery of national sovereignty and genuine discretion in domestic policy making is, after scrutiny, more realistic. It may well be true that supranational institutions currently expand, rather than constrain, the political agency of capital. However, unless such political agency is tackled directly - that is, by asking the question of which alternative political agent can oppose it, be it global labour, transnational European social movements, or new forms of progressive parties such as the Spanish Podemos and the Greek Syriza - it is not clear that a world of states will be any less at the mercy of capital. In other words, the proposal of a European Bretton Woods might overestimate the capacity of the European Union to maintain such a regime in a world where other states carry on playing a different game, as well as underestimate the disruptive power of threats of capital flight and creditors' pressure in a world of ostensibly independent states. It may well be true that we need - roughly speaking - to 'de-globalise': but in order to deglobalise in the right way, we need sufficiently powerful progressive political agents backing up the project. This is crucial if a European Bretton Woods is to play a similar role to the original Bretton Woods and ensure that public ends are prioritised over market openness.

$* * * * * * * * * * * * * * * *$ 
Capital and Buying Time are very different - in style, tone and approach - from the kind of scholarship that political theorists usually engage in. Yet, both have been received with interest, and sometimes enthusiasm, by considerable portions of the discipline. One obvious reason for this is that they do not shy away from offering a normative recipe. Their prescriptions, as we have seen, widely diverge and are informed by an extremely nonideal reading of our current socio-political predicament-but they do express the unpopular conviction that the social sciences should tackle questions about 'what is to be done'. However, the presence of two normative proposals which theorists can engage with is not, I think, the only reason why these two books are rightly perceived as being relevant to political theory. There are, I think, two additional reasons, which this review article has sought toillustrate.

First, as we have seen, although the two authors have very different sensitivities towards the relationship between politics and economics, they are both problematically silent on one fundamental point: if their analyses are correct, where can a progressive political force able to counteract their gloomy predictions come from? Capital and Buying Time offer two very different recipes on what ought to be done to address the problems they raise - but it is not clear which actor, or combination of actors, can be the driving force behind them, and how so. A third book on this remains to be written. I am not hereby suggesting that this book should be one of 'pure' political theory - for it would have to address a plethora of empirical questions. However, this remark highlights how crucial it is for normative as well as empirical and strategic questions about political agency to be revitalised. The two central concerns of contemporary normative political theory are identifying the correct political ideal and the institutional setting or policy that would bring it about. Yet Capital and Buying Time teach us - perhaps more through their lacunae than through their impressive achievements - that without an account of political agency, we cannot know how the right policies could be either implemented or sustained over time. Thus, one further sense in which Piketty and Streeck teach us, that there's more to Marx than social-democrats would acknowledge, is that the search for the emancipatory agent matters just as much as the definition of what counts as emancipation from a normative and institutional point of view. Questions of political agency and forms of political solidarity need to be put back on political theory's agenda. ${ }^{3}$

Second, and relatedly, the crisis of social-democratic optimism which both Capital and Buying Time so eloquently (if differently) express raises animportant question for normative political theorists, especially for those who are animated by a motivation to guide action. The lesson is the following: sometimes, counterintuitively, reality presses us to be more, rather than less, radical than our ideals would seem to indicate. Both Piketty and Streeck, it is worth repeating, endorse social-democracy and the European social model as ideals. They do not share the Marxist creed that social democracy is but a pale and highly compromised version of what a truly equal society could be. In this, they resonate with the general spirit of much liberal egalitarian literature: the main aim of social justice should be to achieve a careful balance of freedom, equality and efficiency, rather than prioritise 
one of these values over the other two. The ideal-type of the European social model does that. In this sense, social-democracy - with its regulation of, rather than opposition to, capitalism - is the ideal, rather than the second best. If, however, Piketty and Streeck are roughly correct in their respective diagnoses, social democracy might actually be the true Utopia, for a peaceful taming of capitalism can only obtain in unique and unstable circumstances. If that is the case, social democrats and liberal egalitarians who care about being action-guiding might need to adopt a more confrontational stand towards capitalism - not because they think that radically anti-capitalist models are the ideal, but because the 'ideal compromise' which they endorse might prove to be a waste of time. Like Piketty and Streeck, they might have to become reluctant radicals. To put it as clearly as possible: tamed capitalism might be the best (because it balances different values rather than choosing one abother all others), but if taming capital and forcing it to serve public ends is impossible or cannot be a stable equilibrium, liberal egalitarians must choose whether to take a more radical anti-capitalist stand or not.

\section{Declaration of conflicting interests}

The author(s) declared no potential conflicts of interest with respect to the research, authorship, and/or publication of this article.

\section{Funding}

The author(s) received no financial support for the research, authorship, and/or publication of this article.

\section{Notes}

1. Note, again, how this resonates with Piketty's main point. In a traditional paradigm, investors would worry about austerity because it would depress mass consumption too much. If $r>g$, however, capital need not always worry about a depressed economy.

2. See also Mair (2013).

3. Admittedly, political theorists are starting to become aware of this (Ronzoni, forthcoming; White and Ypi, 2011).

\section{References}

Kalecki M (1943) Political aspects of full employment. Political Quarterly 14(4): 322-331.

Mair P (2009) Representative versus responsible government. Max Planck Institute for the Study of Societies Working Paper 09/8. Available at: www.mpifg.de/pu/workpap/wp098.pdf (accessed 27 July 2015).

Mair P (2013) Ruling the Void: The Hollowing of Western Democracy. New York/London: Verso.

Piketty T (2014) Capital in the 21st Century. Cambridge, MA: Harvard University Press, p.696, ISBN: 9780674430006.

Piketty T et al. (2014) Our manifesto for Europe. The Guardian. Available at: www.theguar dian.com/commentisfree/2014/may/02/manifesto-europe-radical-financial-democratic (accessed 27 July 2015). 
Ronzoni M (forthcoming) Global labour injustice: A critical overview. In: Yossi D et al. (eds) Global Justice and International Labour Law. Cambridge, UK: Cambridge University Press.

Streeck W (2013) Vom DM-Nationalismus zum Euro-Patriotismus? Eine Replik auf Juưgen Habermas. Blatter für deutsche und internationale Politik 13: 75-92. Available at: www.blaetter.de/archiv/jahrgaenge/2013/september/vom-dm-nationalismus-zum-euro -patriotismus (accessed 27 July 2015).

3 Streeck W (2014) Buying Time: The Delayed Crisis of Democratic Capitalism. New York/ London: Verso, p.240, ISBN: 9781781685495.

White J and Ypi L (2011) On partisan political justification. American Political Science Review 105(2): 381-396. 